\title{
Evaluation of Materials and Surface Treatments for the DWPF Melter Pour Spout Bellows Protective Liner
}

by

K. J. Imrich

Westinghouse Savannah River Company

Savannah River Site

Aiken, South Carolina 29808

D. F. Bickford

G. G. Wicks

This paper was prepared in connection with work done under the above contract number with the U.S. Department of Energy. By acceptance of this paper, the publisher and/or recipient acknowledges the U.S. Government's right to retain a nonexclusive, royalty-free license in and to any copyright covering this paper, along with the right to reproduce and to authorize others to reproduce all or part of the copyrighted paper. 


\title{
EVALUATION OF MATERIALS AND SURFACE TREATMENTS FOR THE DWPF MELTER POUR SPOUT BELLOWS PROTECTIVE LINER (U)
}

\author{
KENNETH J. IMRICH \\ DENNIS F. BICKFORD \\ \& \\ GEORGE G. WICKS
}

SAVANNAH RIVER TECHNOLOGY CENTER

Publication Date: June 27, 1997

Westinghouse Savannah River Company Savannah River Site Aiken, SC 29808

PREPARED FOR THE U.S. DEPARTMENT OF ENERGY UNDER CONTRACT DE-AC09-89SR18035 PRESENTLY UNDER CONTRACT DE-AC09-89SR18035 


\section{DISCLAIMER}

This report was prepared as an account of work sponsored by an agency of the United States Government. Neither the United States Government nor any agency thereof, nor any of their employees, makes any warranty, express or implied, or assumes any legal liability or responsibility for the accuracy, completeness, or usefulness of any information, apparatus, product, or process disclosed, or represents that its use would not infringe privately owned rights. Reference herein to any specific commercial product, process, or service by trade name, trademark, manufacturer, or otherwise does not necessarily constitute or imply its endorsement, recommendation, or favoring by the United States Government or any agency thereof. The views and opinions of authors expressed herein do not necessarily state or reflect those of the United States Government or any agency thereof.

This report has been reproduced directly from the best available copy.

Available to DOE and DOE contractors from the Office of Scientific and Technical Information, P.O. Box 62, Oak Ridge, TN 37831; prices available from (615) 576-8401.

Available to the public from the National Technical Information Service, U.S. Department of Commerce, 5285 Port Royal Road, Springfield, VA 22161. 


\section{DISCLAIMER}

Portions of this document may be illegible electronic image products. Images are produced from the best available original document. 
Keywords:

DWPF

Melter

Corrosion

Tests

Coatings

BLD-221S

Retention: Lifetime

\section{EVALUATION OF MATERIALS AND SURFACE TREATMENTS} FOR THE DWPF MELTER POUR SPOUT BELLOWS

PROTECTIVE LINER (U)

Kenneth J. Imrich

Dennis F. Bickford

and

George G. Wicks

Issued:

June 27, 1997
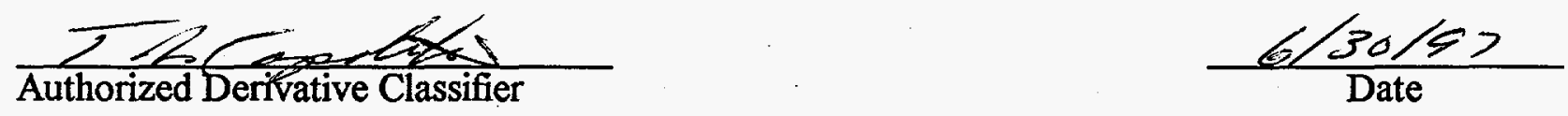

SRTC SAVANNAH RIVER TECHNOLOGY CENTER, AIKEN, SC 29808

Westinghouse Savannah River Company

Prepared For The U.S. Department Of Energy Under Contract DE-AC09-89SR18035 


\section{TITLE: EVALUATION OF MATERIALS AND SURFACE TREATMENTS FOR THE DWPF MELTER POUR SPOUT BELLOWS PROTECTIVE LINER (U)}

\section{APPROVALS}

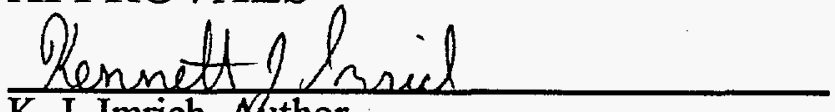

K. J. Imrich, Aluthor

Materials Technology Section

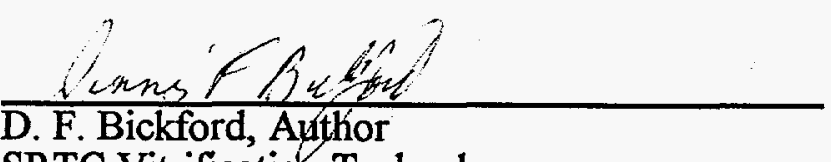

Date:

Date: hene 30,1997

SRTC Vitrification Technology

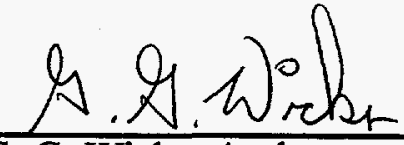

G. G. Wicks, Author

Date: June 30,1997

Focus Area Programs

Bunce \&. Premend

B. J. Wiersna, Technical Reviewer

Materials Technology Section

R.C. Hopkins. Customer Reviewer

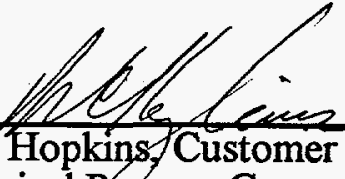

Chemical Process Group

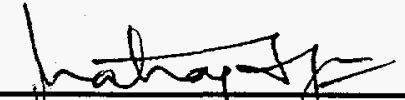

N. C. Iyer, Manager

Materials Applications \& Corrosion Technology Group

Materials Technology Section

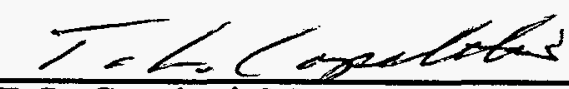

T. L. Capeletti, Manager

Materials Technology Section
Date: July 1, 1997

Date:

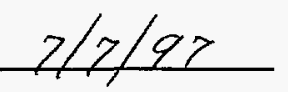

Date: $6 / 30 / 2$ 


\section{Evaluation Of Materials And Surface Treatments For The DWPF Melter Pour Spout Bellows Protective Liner (U)}

\section{Summary}

A study was undertaken to evaluate a variety of materials and coatings for the DWPF pour spout bellows liner. The intent was to identify materials that would minimize or eliminate adherence of glass on the bellows liner wall and help minimize possible pluggage during glass pouring operations in DWPF. Glass has been observed adhering to the current bellow's liner, which is made of 304L stainless steel. Materials were identified which successfully allowed molten glass to hit these surfaces and not adhere. Results of this study suggest that if these materials are used in the pouring system glass could still fall into the canister without appreciable plugging, even if an unstable glass stream is produced. The materials should next be evaluated under the most realistic DWPF conditions possible.

The glass sticking temperature was used as the performance criteria in these studies. This temperature is defined as the lowest temperature at which a glass bead sticks to the coupon and cannot be dislodged with minimal force. Materials and coatings generally exhibit good performance at temperatures at or below the glass sticking temperature range. Results of the screening tests indicated that materials with high thermal conductivities, namely, sterling silver, Consil $^{\circledR} 995$ [99.4 wt\% Ag / 0.25 MgO / $0.25 \mathrm{Ni}$, oxygen-free copper pre-oxidized at $900^{\circ} \mathrm{C}$, and aluminum and the non-wetting, non-metallic materials such as boron nitride, pure graphite, and carbon/carbon fiber composite had superior performance, i.e., highest glass sticking temperatures. Glass would stick to the latter group of materials; however, unlike the metal coupons e.g., Type 304L stainless steel, the glass would spall off when the temperature was allowed to decrease slightly. Other candidate materials that performed satisfactorily were the CDA $706(90 \mathrm{Cu} / 10 \mathrm{Ni})$ and the Nickel 200 . Glass delaminated from these materials at the oxide/glass interface upon cooling to room temperature.

Other findings of this study include the following:

Increasing coupon thickness produced a favorable increase in the glass sticking temperature.

Highly polished surfaces, with the exception of the oxygen-free copper coupon coated with Armoloy dense chromium, did not produce a significant improvement in the glass sticking temperature. Increasing angle of contact of the coupon to the falling glass did not yield a significant performance improvement.

Electroplating with gold and silver and various diffusion coatings did not produce a significant increase in the glass sticking temperature. However, they may provide added oxidation and corrosion resistance for copper and bronze liners. Boron nitride coatings delaminated immediately after contact with the molten glass.

Candidate materials with good resistance to glass sticking that should be considered for future testing in conditions representative of the DWPF bellows region are carbon/carbon composite, boron nitride, Nickel 200, Consi ${ }^{\circ}$ 995, oxygen-free copper, and CDA 706. 


\section{Glass Pouring Problems \& Potential Remedies}

The DWPF has experienced glass pouring anomalies during its operations. A substantial effort has been undertaken to understand and correct these anomalies. Independent teams have concluded that they are most likely caused by multiple factors. Potential remedies can be grouped into two main categories [1]:

1) actions to "stabilize the molten glass stream" as it exits to either minimize or eliminate "wicking problems" and subsequent glass pluggage e.g., redesign of the pour spout insert and

2) actions involving engineering around an inherently unstable glass stream through the use of a non-stick bellows liner. Such a protective liner would preclude the build-up of glass when the glass stream contacts the liner wall and funnel it into the canister.

The ideal solution would include a combination of these two remedies, i.e., stabilization of the glass stream and also redundant engineering solutions should the stable stream de-stabilize during operations.

The objective of the present technical report is to discuss results of an investigation aimed at evaluating non-stick coatings and alternative materials for the melter pour spout bellows protective liner. These materials can potentially provide an important "insurance policy" to either minimize or eliminate future glass pluggage in the pouring region. This concept would allow glass to fall into the canister even if the stream becomes unstable. The bellows liners are removable and are of modular design. Thus, implementing this concept would be reversible and pose no significant risk to the melter and glass quality.

\section{Background}

The Materials Technology Section (MTS) was requested by DWPF and Vitrification Technology to evaluate various materials and surface treatments for possible application to the DWPF melter pour spout bellows protective liner. Pour stream instability has been observed throughout cold and radioactive operations. As a result, glass wicked down the side of the pour spout and into the bellows where it solidified. During cold runs, glass was removed from the bellows by mechanical cleaning (scraping). Cleaning the bellows during radioactive operations was impossible. Therefore, a Type $304 \mathrm{~L}$ stainless steel replaceable liner was developed to protect the bellows from the glass (Figure 1). However, glass still periodically adhered to the protective liner thus restricting the flow of glass in this region of the pour spout. Depending on the stability of the pour stream, pluggages resulted in as little as one day of melter operation. The liner was mechanically cleaned by dropping a $150 \mathrm{lb}$ weight through the center knocking free any adhering glass and effectively extending liner life. The liners are discarded when they were deformed and no longer fit into the bellows. Direct temperature measurements in the bellows have not been taken, but they are expected to range between 400 and $500{ }^{\circ} \mathrm{C}$. Temperature of the liner is expected to approach the temperature of the molten glass $\left(800-900^{\circ} \mathrm{C}\right)$ if the glass remains in contact with the liner for extended periods of time, or if large gobs of glass are involved. The temperature may also be higher at the top of the bellows, closest to the heated pour spout.

Screening tests performed as part of this study were designed to determine the lowest temperature at which molten glass will adhere to various materials and coatings while in air (referred to as the 
glass sticking temperature). This screening test was intended solely to determine the relative temperature at which molten glass will adhere to various materials and coatings in air. The DWPF melter pour spout environment is complex and contains various halide and sulfate salts. In addition, glass contacting the bellows is expected to have a wide range of temperatures and flow rates. Screening tests performed as part of this study are not intended to model this environment. Therefore, performance of these materials may be different in the melter pour spout environment. Further testing would be necessary to evaluate the formation, stability and performance of the oxides in this complex environment. Such testing requires temperature measurement of the actual DWPF meiter bellows liner. Engineering verification will require full scale testing of candidate materials under realistic pouring conditions.

\section{Experimental Apparatus and Test Procedures}

A small melter capable of melting 300 grams of glass per batch (Figure 2) was constructed. The test apparatus consisted of two independently controlled pairs of ceramic fiber heaters surrounding an Inconel 690 box (dimensions, $10.2 \mathrm{~cm}$ by $7.6 \mathrm{~cm}$ by $10.2 \mathrm{~cm}$ ) and an Inconel 690 drain tube $(7.6 \mathrm{~cm}$ long with a $4.5 \mathrm{~mm}$ inner diameter). Both the heaters and the area below the drain were covered with an insulating blanket and/or fiber board. Test specimens were placed on a hot plate approximately $7.5 \mathrm{~cm}$ below the drain. The hot plate was not insulated. Coupons were tested at 45 and 80 degree angles to the horizontal plane.

Most of the plate coupons were $0.318 \mathrm{~cm}$ thick; however, one thicker $(0.953 \mathrm{~cm})$ coupon was fabricated from each of the following materials, Type 304L stainless steel (304L), oxygen-free copper, and aluminum. Dimensions of the coupons are shown in Appendix 2. Coupons were either used in the as-received condition (generally better than a 600 grit finish), ground to a 600 grit finish or polished to a 1 micron finish. All coupons were cleaned with ethyl alcohol prior to testing. The thickness of the silver and gold electroplating on the copper and 304L coupons was 2.54 microns $(0.0001$ in). Type $304 \mathrm{~L}$ stainless steel coupons were also coated with Carborundum Combat ${ }^{\circ}$ boron nitride (Type $A$ and $S$ pastes and aerosol spray) according to the manufacturer specifications (Appendix 1). See Table 1 for a list of candidate materials and surface treatments.

Temperature data were obtained from commercial grade thermocouples that were placed in the molten glass, at the end of the drain, and on the specimen near where the glass contacted the specimen. The three thicker coupons were drilled to accommodate an additional thermocouple oriented in the middle of the coupon just beneath the glass contact area.

Testing was performed by melting glass from DWPF cold run canister S00407 at approximately $1050{ }^{\circ} \mathrm{C}$. The drain was maintained at approximately $1025^{\circ} \mathrm{C}$ which would yield glass temperatures between 760 to $830{ }^{\circ} \mathrm{C}$ on the surface of the test specimen. All tests were performed in air. Glass exited the drain and formed a bead approximately $5 \mathrm{~mm}$ in diameter every 7 to 10 seconds. The test specimens were heated using a hot plate (maximum temperature 500 ${ }^{\circ} \mathrm{C}$ ) from ambient to the temperature where glass would stick on the coupon. As the plate was heated the glass bead was observed in order to determine whether or not it adhered to the coupon. A piece of Inconel weld wire was used to push the glass bead off the coupon when it began to stick. The temperature at which the bead could not be dislodged from the coupon using minimal force was defined as the "glass sticking" temperature. Higher sticking temperatures are beneficial, as this would allow a broader operational temperature range in the bellows. 


\section{$\underline{\text { Results }}$}

\section{General Observations}

Results of the screening tests indicated that high thermal conductivity materials namely, copper, sterling silver, Consil ${ }^{3} 995$ and aluminum had the best (highest) glass sticking temperatures of all the metallic materials. Solid graphite, boron nitride, and the carbon/carbon fiber composite performed extremely well with glass sticking temperatures ranging from 440 to $510^{\circ} \mathrm{C}$ (Table 2). When glass stuck to these materials it could be removed by lowering the temperature slightly. Highly polished surfaces ( 1 micron or better) did not provide a significant performance advantage over a machined surface (32 $\mathrm{rms}$ ) or ground surface (600 grit $/ \sim 17$ micron). Increasing the planar slope of the coupons also did not appear to affect the glass sticking temperature significantly. Further testing at an angle of 80 degrees was discontinued. Data from these tests are recorded in Lab Notebook WSRC-NB-93-30.

\section{Type 304 L Stainless Steel and Inconel 690}

Glass was observed to stick to the $0.318 \mathrm{~cm}(0.125$ in) thick, $304 \mathrm{~L}$ stainless steel coupon at temperatures between 285 and $313{ }^{\circ} \mathrm{C}$. Surface coatings, highly polished surfaces, and electroplating with gold or silver did not significantly increase the temperature at which glass would begin to stick. Temperature of the thicker, $0.953 \mathrm{~cm}(0.375 \mathrm{in})$, coupon exceeded $400^{\circ} \mathrm{C}$ before the glass began to stick.

Glass stuck to the pre-oxidized $\left(900^{\circ} \mathrm{C}\right)$ Inconel 690 coupon at $290^{\circ} \mathrm{C}$. The glass did not spall off during cooling and was also difficult to remove at room temperature. The oxide scale was thick and uniform.

Polished and as-received coupons formed a thin gold colored oxide, similar to the pre-oxidized coupon, when heated on the hot plate above $400^{\circ} \mathrm{C}$. A blue oxide was observed on these coupons around the glass contact area. Glass tenaciously bonded to this oxide and could not be removed at room temperature even with vigorous mechanical cleaning (Figure 3). Removal of glass at room temperature from the electroplated and diffusion coated coupons was significantly easier than cleaning the oxidized samples.

Boron nitride pastes and the aerosol spray on the copper and 304L coupons spalled either after application or as the glass contacted the coated coupon. The spray contained numerous organic binding agents/solvents (i.e. propane, butane, acetone, and ethylcellulose) and burned immediately upon contact with the molten glass. After the boron nitride spalled, glass would stick to the exposed stainless steel surface at temperatures comparable to the other $0.318 \mathrm{~cm}$ thick coupons.

\section{Copper Coupons}

The glass sticking temperature for the various copper coupons ranged from 363 to $440{ }^{\circ} \mathrm{C}$. This was significantly higher (approximately $100^{\circ} \mathrm{C}$ ) than the $304 \mathrm{~L}$ and Inconel 690 . Generally, diffusion and electroplated coatings, did not prove beneficial with respect to glass sticking; however, these coatings may increase life of copper alloys by reducing corrosion and/or oxidation. However, the polished dense chromium coated coupon did show a significant improvement with the glass beginning to adhere around $440^{\circ} \mathrm{C}$. As-received and polished copper coupons formed a non-uniform loosely adhering scale during the test. Although this scale spalled readily, glass would stick to the exposed copper substrate. Any glass which remained after cooling to room temperature could be removed by mechanically cleaning. The force necessary to clean the glass 
deposits from these coupons was significantly less than that required to remove the glass from the stainless steel coupons. Increasing coupon thickness was beneficial, resulting in a corresponding increase in the glass sticking temperature.

The Copper Development Association alloy CDA 706 formed a uniform oxide scale that would bond with the glass. However, upon cooling the glass would delaminate at the oxide metal interface and slide off. Oxide from the coupon was observed on the glass surface which was in contact with the coupon (Figure 4). This oxide layer would quickly reform on the coupon so the glass never bonded with the copper substrate.

The copper coupon pre-oxidized at $900{ }^{\circ} \mathrm{C}$ had the lowest glass sticking temperature, $341{ }^{\circ} \mathrm{C}$, when compared to the other copper coupons. This coupon contained a very thick black uniform scale. As was observed with the CDA 706 coupon, the glass would delaminate upon cooling. The copper substrate was never exposed during the approximately 30 minute test and it was difficult to determine if this oxide was degrading (thinning) or reforming during the test.

\section{Graphite, Carbon /Carbon Fiber Composite, and Solid Boron Nitride}

Non-metallic materials including solid boron nitride, graphite, and the carbon/carbon fiber composite had the highest glass sticking temperatures of all materials tested, 440, 510, and 465 ${ }^{\circ} \mathrm{C}$ respectively and hence, exhibited excellent performance. Above this temperature range, glass would stick to these materials. However, it would slide off when the temperature was decreased slightly. These materials did not show any evidence of degradation, including discoloration, as a result of exposure to molten glass.

\section{Other Alternate Materials - Sterling Silver, Consil ${ }^{\circledR}$ 995, Aluminum, and Nickel 200}

Temperatures in excess of $400^{\circ} \mathrm{C}$ were required for glass to stick to materials with a high thermal conductivity, (i.e. sterling silver, Consil ${ }^{\circ} 995$, and 1100 aluminum). These materials shed glass readily upon cooling. The sterling silver and Consil® 995 were slightly discolored, but no degradation was noted. Scale formation on these two materials was minimal. As observed with the copper and stainless steel, increasing thickness of the Consilß 995 increased the sticking temperature. Aluminum formed a white uniform oxide while at elevated temperatures. This scale did not appear to degrade during the test. Nickel 200 , which has a thermal conductivity much lower than the aluminum and sterling silver, performed satisfactorily up to $403^{\circ} \mathrm{C}$. This alloy formed a blue uniform scale and shed glass much like the CDA 706 and copper (pre-oxidized at $90{ }^{\circ} \mathrm{C}$ ) coupons. Glass deposits delaminated from this coupon after cooling to room temperature. The oxide was uniform and in good condition following the test.

\section{Discussion}

Results indicated that materials with a high thermal conductivity, (i.e. sterling silver, Consil ${ }^{\circledR} 995$, copper, and aluminum) had the highest glass sticking temperatures of all the metallic materials tested. High thermal conductivity materials transfer heat readily and if the temperature differential between the molten glass and the coupon is large, the glass will quench rapidly and not remain adhered to the surface. However, as the temperature differential between the molten glass and coupon decreases, bonding (chemical and/or mechanical) can result. This may occur because the chemical reaction is more kinetically favorable at the higher temperatures and because the molten glass is less viscous. Others have shown that decreasing viscosity increases the contact area thus, 
increasing the probability of a chemical bond $[2,3]$. If the glass bonds with the metal substrate or with a tenaciously adhering oxide and the thermal stresses generated upon cooling are not sufficient to break this bond, the glass will not delaminate and slide off. However, if a chemical bond does not exist and/or if the oxide is weakly adhering to the metal substrate, the glass will spall. In order for the latter to occur continually the oxide must reform rapidly. Both the CDA 706 and Nickel 200 appear to perform in this fashion.

Glass stuck to both the 304L (reference material of construction of the current DWPF bellows liner) and the Inconel 690 coupons. These alloys contain chromium and readily form a spinel $\left(\mathrm{NiCr}_{2} \mathrm{O}_{4}\right)$ or chromium oxide $\left(\mathrm{Cr}_{2} \mathrm{O}_{3}\right)$ protective layer in oxidizing environments. The oxide which formed on the $304 \mathrm{~L}$ at $400{ }^{\circ} \mathrm{C}$ was thin and tenaciously bound to the substrate. The glass adhered well to the $304 \mathrm{~L}$ because of this excellent mechanical and the chemical bond resulting from the borosilicate glass affinity for chromium oxide. Pask [4] has shown this for other silicate glasses. The oxide scale on the Inconel 690 coupon (pre-oxidized at $900^{\circ} \mathrm{C}$ ) was not bound as tightly as the scale on the $304 \mathrm{~L}$, thus the glass did not stick as well.

Electroplated and diffusion coatings on copper and $304 \mathrm{~L}$ coupons did not significantly increase the glass sticking temperature. This suggests that the thermal conductivity and the mass (thicker coupons had higher sticking temperatures) of the substrate play a greater role in impeding glass adherence than does surface tension at the lower temperatures. The polished dense chromium coating on the copper coupon was the only coating that showed an improvement in performance. Further testing of this material would be necessary to understand this phenomena.

Non-metallic materials including boron nitride, pure graphite, and the carbon/carbon fiber composite also had high glass sticking temperatures, 440,510 , and $465^{\circ} \mathrm{C}$, respectively. This data represents the temperature at which glass would begin to stick to the coupons under the test conditions. This is a relative number that may change with glass flow rate and temperature of the glass contacting the plate. Above these temperatures glass would stick to these materials. However, unlike the metallic coupons, the glass would slide off when the temperature was decreased slightly. The molten glass did not appear to wet the surface of these materials, especially at the lower temperatures. Therefore, surface tension may play an important role with the ability of these materials to shed molten glass.

Boron nitride aerosol sprays and pastes applied on 304L and copper substrates do not provide adequate protection. Although solid boron nitride performed exceptionally well, the pastes and sprays spall readily, and therefore, do not provide adequate protection. These materials are difficult to apply uniformly and in the case of the aerosol spray, contain volatile organics which ignite upon contact with the molten glass.

Increasing the angle of the coupon plane did not significantly change the glass sticking temperature. This may be because the glass beads were small and their weight was insignificant compared to the surface area adhering to the metal surface. Allowing a large deposit of glass to adhere to the coupon surface or increasing the flow may affect this result.

Future work will be required to evaluate the effects of continuous pouring at rates comparable to that of DWPF. In addition, corrosion, and mechanical properties at elevated temperatures will also need to be considered before selecting primary materials. Although aluminum performed well, it was not considered as a possible candidate material because its low melting point. Mechanical and physical properties of selected materials are presented in Appendix 4 .

The primary focus of this study was the glass sticking temperature. In addition, some mechanical and chemical properties were also included. However, other factors must be considered before 
selection of a candidate material for the fabrication of a prototype liner can be made. As discussed previously corrosion/oxidation resistance in the pour spout environment is a primary concern. Other factors that must be considered are available product forms, fabricability, affect on glass quality and total cost, including both material and fabrication costs. The table in Appendix 5 compares these factors relative to 304L. With the exception of boron nitride, all materials are available in the required product forms. Excluding the carbon/carbon fiber composite, candidate materials should not adversely affect glass quality. The carbon/carbon fiber composite needs further evaluation because of limits on organics in the glass. All of the candidate materials are fabricable although special processes, e.g. weld filler materials and procedures, may be required. Total material and fabrication costs relative to $304 \mathrm{~L}$ are presented in Appendix 5. The carbon/carbon fiber composite material is most expensive because initial tooling costs will be high.

\section{Conclusions}

Based on the results of this study the conclusions are:

1) Glass adhered tenaciously to oxidized Type $304 \mathrm{~L}$ stainless steel even at room temperature. This oxide formed readily at temperatures greater than $400^{\circ} \mathrm{C}$.

2) Materials were identified that would resist glass sticking in a temperature range expected to exist in the DWPF pour spout bellows region.

- Non-metallic materials including solid boron nitride, graphite, and the carbon/carbon fiber composite had the highest glass sticking temperatures of all materials tested. The temperatures were 440,510 , and $465^{\circ} \mathrm{C}$, respectively.

- Materials with a high thermal conductivity, (i.e. sterling silver, Consil ${ }^{89} 95$, copper, and aluminum) had the highest (best) glass sticking temperatures of all the metallic materials tested. The temperatures were, $418,400,375$, and $403{ }^{\circ} \mathrm{C}$, respectively.

3) Increasing coupon thickness (i.e. increasing the thermal mass) raised the glass sticking temperature, decreasing the tendency to stick.

4) Highly polished surfaces did not provide a significant performance advantage over a machined surface.

5) Glass spalled from the CDA 706, Nickel 200 and the oxygen-free copper pre-oxidized at 900 ${ }^{\circ} \mathrm{C}$ by delaminating at the oxide / metal interface.

6) Coatings intended to alter the surface chemistry of the coupon (i.e. sterling silver, gold, and chromium) did not have a significant effect on the glass sticking temperature, except for the polished dense chromium coating. These coatings may be beneficial in decreasing oxidation and corrosion rates.

7) Changing the angle of the coupon planar surface from 45 to 80 degrees did not have a significant effect on the glass sticking temperature. 


\section{Proposed Future Work}

Full scale testing of portions of the bellows liner is recommended using candidate materials identified from the screening tests. These materials include; carbon/carbon composite, boron nitride, Nickel 200, Consil 995, oxygen-free copper, and CDA 706. The temperature profile of the upper portion and the funnel region of the DWPF melter bellows liner should be directly determined. Temperature indicating paints have been provided to DWPF for this purpose. Full scale tests should then be performed at representative temperatures with hot glass at DWPF pour rates for extended periods of time. Testing should also include evaluation of the oxidation and corrosion resistance of the materials under representative conditions.

\section{References}

1. J. Morin, Kepner-Trego Final Report, OPS-DTP-970070, April 29, 1997.

2. McGraw, D.A., Transfer of Heat in Glass During Forming, Journal Of The American Ceramic Society, Vol. 44, No. 7 (1961).

3. Falipou, M. and Donnet, C., Sticking Temperature Investigation of Glass/Metal Contacts Determination of Influencing Parameters, Glastech. Ber. Glass Science Technology, Vol. 70, No. 5, (1977).

4. Pask, J.A. and Fulrath, R.M., Fundamentals of Glass-to-Metal Bonding: VII, Nature of Wetting and Adherence, Journal Of The American Ceramic Society, Vol. 45, No. 12 (1962). 
Table 1. Candidate Materials and Surface Treatments for Bellows Protective Liner Screening Tests *.

\begin{tabular}{|c|c|}
\hline $\begin{array}{c}\text { Materials } \\
\text { Tested }\end{array}$ & $\begin{array}{l}\text { Material } \\
\text { Condition }\end{array}$ \\
\hline \multirow{11}{*}{$\begin{array}{l}\text { Type 304L Stainless Steel } \\
\text { (reference material for current } \\
\text { bellows liner) }\end{array}$} & As-received \\
\hline & Polished 1 micron \\
\hline & Polished 600 grit (17 micron) \\
\hline & Gold Plated $(0.0001 \mathrm{in})$ \\
\hline & Silver Plated (0.0001 in) \\
\hline & Dense Chromium (Armoloy) \\
\hline & Oxidized $400^{\circ} \mathrm{C}$ \\
\hline & Siliconized Alon \\
\hline & ChromePlex (Cr-Si) Alon \\
\hline & Bidiffused (Cr/A1/Si) Alon \\
\hline & Polished 600 grit (17 micron) \\
\hline Inconel 690 & Oxidized $900^{\circ} \mathrm{C}$ \\
\hline \multirow[t]{7}{*}{ Oxygen-Free Copper } & As-received \\
\hline & Polished 1 micron \\
\hline & Polished 600 grit (17 micron) \\
\hline & Gold Plated $(0.0001$ in) \\
\hline & Silver Plated $(0.0001$ in $)$ \\
\hline & Dense Chromium (Armoloy) \\
\hline & Polished 600 grit (17 micron) \\
\hline Sterling Silver & Polished 600 grit (17 micron) \\
\hline Consil\& 995 & As Received (better than 600 grit) \\
\hline Corisil@ 995 & Oxidized ( $732 \mathrm{C}, 40$ minutes) \\
\hline Aluminum (1100) & Polished 600 grit (17 micron) \\
\hline Boron Nitride (solid) & Polished 600 grit (17 micron) \\
\hline Boron Nitride Combat@ & Spray (304L Substrate) \\
\hline Boron Nitride Combat ${ }^{8}$ & Paste Type A (304L Substrate) \\
\hline Boron Nitride Combat@ & Paste Type S (304L Substrate) \\
\hline Graphite & Polished 600 grit (17 micron) \\
\hline Carbon/Carbon Composite & As Received \\
\hline Nickel 200 & Polished 600 grit (17 micron) \\
\hline Copper Nickel CDA $706(90 / 10)$ & Polished 600 grit (17 micron) \\
\hline
\end{tabular}

* See Appendix 2 for dimensions of individual coupons. 
Table 2. Temperature/Range Where Glass Sticking Was First Observed on the $(0.125$ in $/ 0.318 \mathrm{~cm})$ Thick Coupons ${ }^{1}$.

\begin{tabular}{|l|c|}
\multicolumn{1}{|c|}{$\begin{array}{c}\text { Material } \\
\text { Tested }\end{array}$} & $\begin{array}{c}\text { Glass Sticking } \\
\left.\text { Temperature/Range }{ }^{\circ} \mathrm{C}\right)^{2}\end{array}$ \\
\hline $\begin{array}{l}\text { Type 304L Stainless Steel (reference material for } \\
\text { current bellows liner) }\end{array}$ & $280-313$ \\
\hline Inconel 690 (60wt\% Ni / 30 wt\% Cr / 7wt\% Fe) & 290 \\
\hline Oxygen-Free Copper (99.9 wt\% Cu) & $341-440$ \\
\hline Sterling Silver (92 wt\% Ag / 8 wt\% Cu) & 418 \\
\hline Consil 8995 (99.5 Ag/0.25 Mg/0.25Ni) & $390-400$ \\
\hline Aluminum 1100 (99.9 wt\% Al) & 403 \\
\hline Boron Nitride (Solid) & 440 \\
\hline Boron Nitride (Spray and Pastes) & $280-290$ \\
\hline Graphite & 510 \\
\hline Carbon/Carbon Composite & 465 \\
\hline Nickel 200 (99.9 wt\% Ni) & 403 \\
\hline Copper Nickel CDA 706 (90 wt $\% \mathrm{Cu} / 10 \mathrm{wt} \% \mathrm{Ni})$ & 430 \\
\hline
\end{tabular}

1 Glass did not stick below these temperatures and the materials performed adequately.

2 Temperatures reported are for all coupons tested (i.e. as-received, coated, and polished). See Appendix 3 for individual coupon data. 
Figure 1. Photograph showing the current DWPF Melter Type 304 L Stainless Steel bellows protective liner.

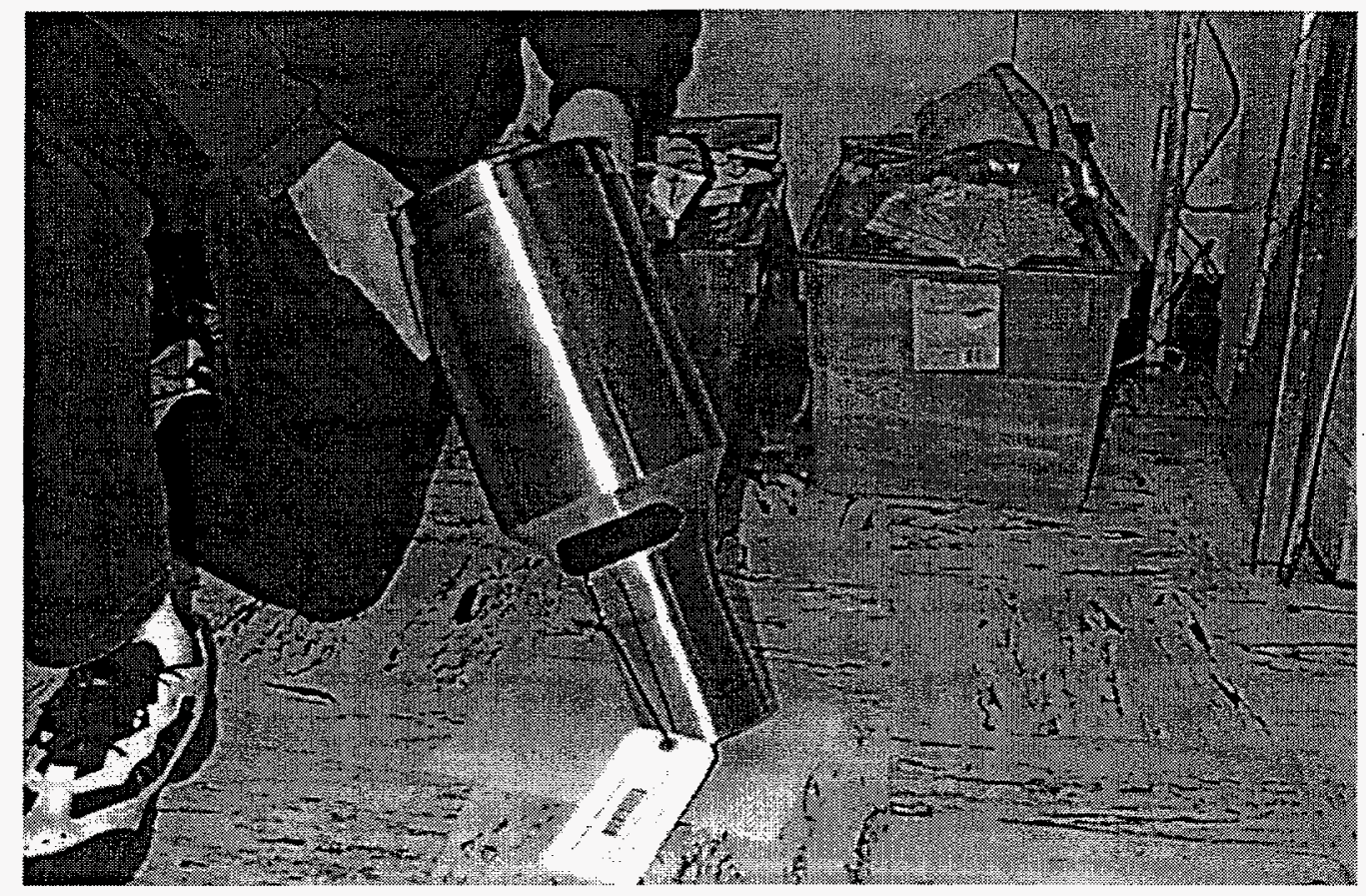




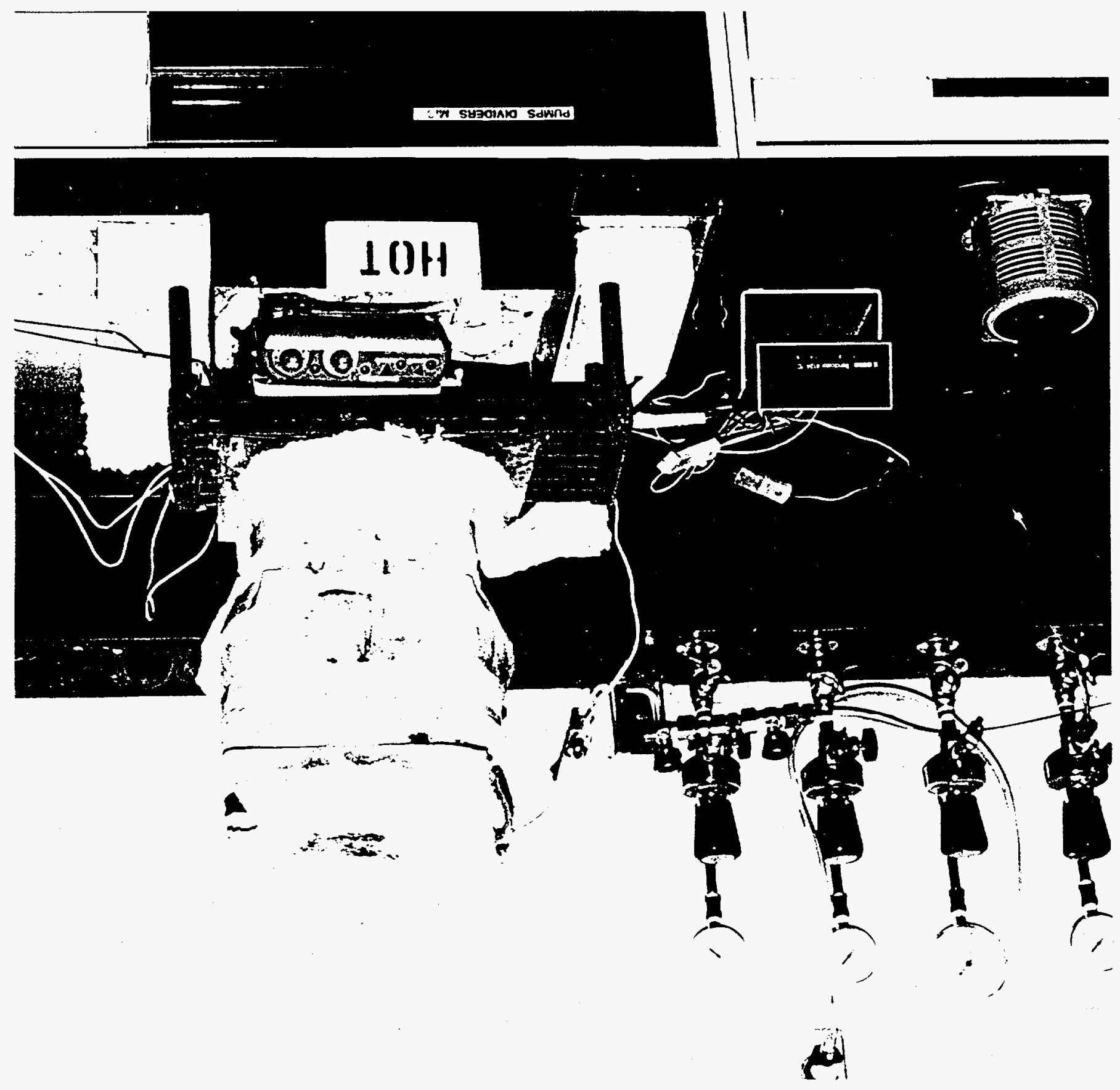

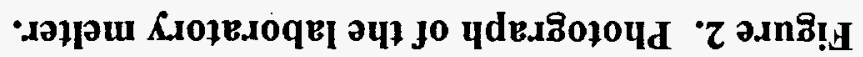


Figure 3. Photograph of various test coupons including the pre-oxidized Type $304 \mathrm{~L}$ Stainless Steel coupon (lowermost coupon). Note glass deposit on 304L Stainless Steel coupon.






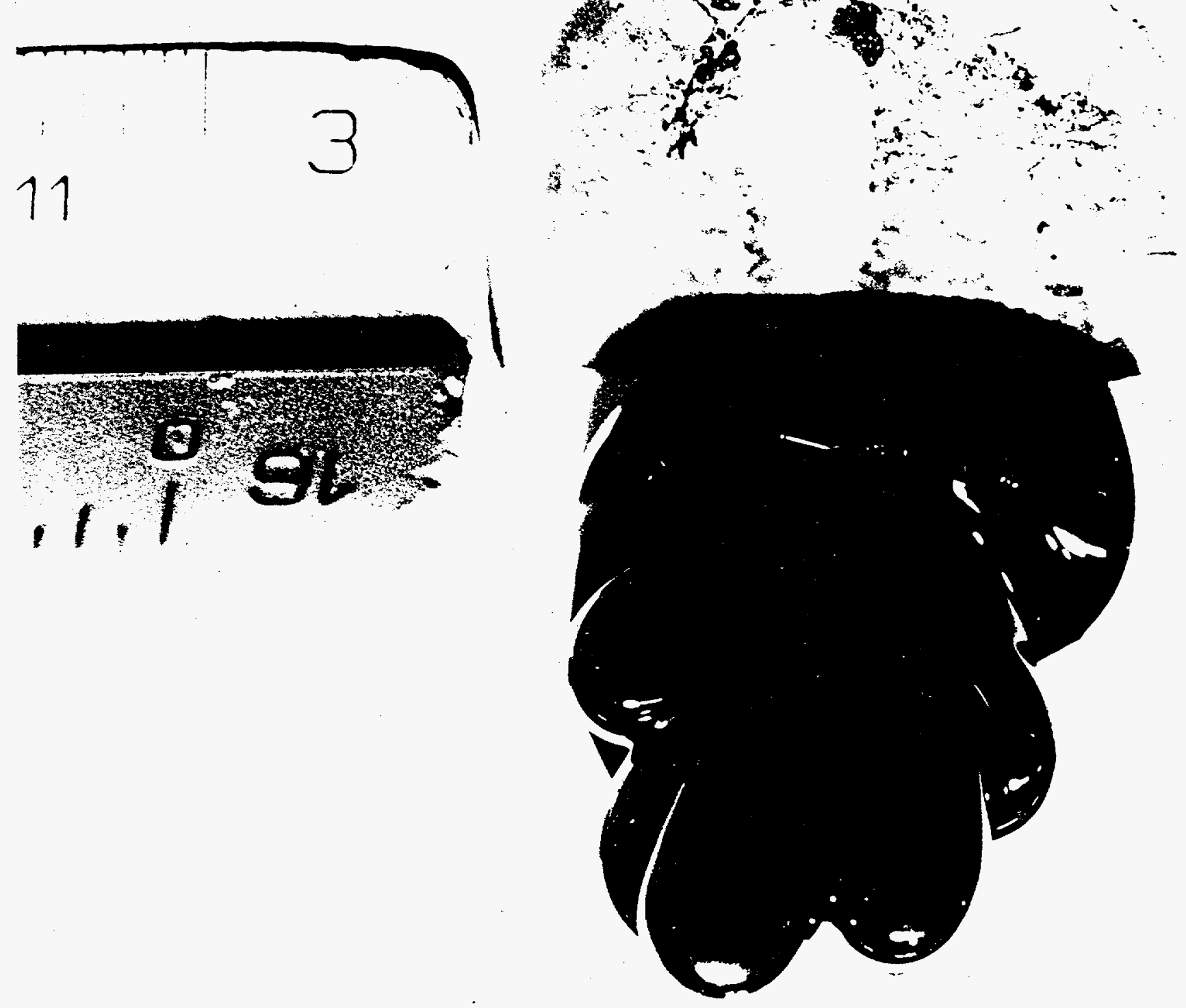

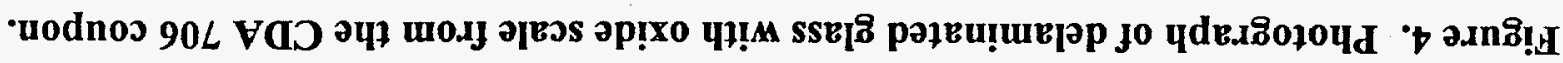




\section{Appendix 1}

\section{Application instructions for Carborundum Combat boron nitride pastes and aerosol spray.}

Combat ${ }^{\circ}$ Boron Nitride Coatings (Table 7 )

\begin{tabular}{|c|c|c|c|c|c|c|}
\hline \multirow{6}{*}{\multicolumn{3}{|c|}{$\begin{array}{l}\text { Features } \\
\text { - Inorganic } \\
\text { - Composed of } \mathrm{BN} \text { and a high temperature inorganic bond phase } \\
\text { in an aqueous medium } \\
\text { - Four grades: E. S. V. A } \\
\text { - Economical method of laking advantage of BN properties } \\
\text { - Applied to a dean, roughened surtace by spraying. painting, or } \\
\text { dipping } \\
\text { - Maximum use temperatures are } 1370^{\circ} \mathrm{C} \text { in reducing atmospheres } \\
\text { and } 700^{\circ} \mathrm{C} \text { in oxidizing atmospheres. }\end{array}$}} & \multicolumn{4}{|c|}{$\begin{array}{l}\text { Propertles } \\
\text { Crystal structure: Hexagonal }\end{array}$} \\
\hline & & & \multicolumn{2}{|c|}{ Color: } & White & \\
\hline & & & \multicolumn{2}{|c|}{ Dielectric strength: } & 790 volts/mil & \\
\hline & & & \multicolumn{3}{|c|}{ Coefficient of friction: $0.2-0.7$} & \\
\hline & & & \multicolumn{2}{|c|}{ Electrical resistivity } & $>2 \times 10^{14}$ & \\
\hline & & & \multicolumn{2}{|c|}{ Specitic gravity: } & 2.25 & $\therefore$ \\
\hline Percent BN & $\begin{array}{l}\text { Type E } \\
80\end{array}$ & $\begin{array}{l}\text { Type S } \\
65\end{array}$ & & \multicolumn{2}{|l|}{$\begin{array}{l}\text { Type V } \\
92\end{array}$} & $\begin{array}{l}\text { Type A } \\
75\end{array}$ \\
\hline Binder & Alumina & Alumina & & \multicolumn{2}{|c|}{ Magnesium Silicate } & Aluminum Phosphate \\
\hline \multicolumn{7}{|l|}{ Appllcation Methods } \\
\hline $\begin{array}{l}\text { Spray } \\
\text { Use Binks No. } 7 \text { gun or } \\
\text { equivalent and air at } 50 \text { psi }\end{array}$ & $\begin{array}{l}\text { Apply layers .001" thick. Air } \\
\text { dry for } 20 \text { mirutes bet- } \\
\text { ween layers. Maximum } \\
\text { thickness. } 008 \text {. }\end{array}$ & \multicolumn{2}{|c|}{$\begin{array}{l}\text { Apply layers .001" thick Air } \\
\text { dry for } 20 \text { minutes bet. } \\
\text { meen layers. Maximum } \\
\text { thickness, .008". }\end{array}$} & \multicolumn{2}{|c|}{$\begin{array}{l}\text { Apply layers } .002^{*} \text { thick. } \\
\text { Air dry lor } 20 \text { minutes bet- } \\
\text { woen layers. Maximum } \\
\text { thickness, 010: }\end{array}$} & $\begin{array}{l}\text { Apply layers } .002^{\circ} \text { thick. } \\
\text { Air dry for } 30 \text { minutes bet- } \\
\text { ween layers. Maximum } \\
\text { thickness. } 010^{\circ}\end{array}$ \\
\hline $\begin{array}{l}\text { Bqush } \\
\text { Use soft bristle brush }\end{array}$ & $\begin{array}{l}\text { Air dry } 20-30 \text { minutes bet- } \\
\text { ween layers. Maximum } \\
\text { thickness, } 008^{*} \text {. }\end{array}$ & \multicolumn{2}{|c|}{$\begin{array}{l}\text { Air dry } 20-30 \text { minutes bet- } \\
\text { woen layers. Maximum } \\
\text { thickness, } 008:\end{array}$} & \multicolumn{2}{|c|}{$\begin{array}{l}\text { Air dry } 30 \text { minutes bet- } \\
\text { ween layers. Maximum, } \\
\text { thickness, } 010^{\circ}\end{array}$} & $\begin{array}{l}\text { Air dry } 60 \text { minutes bet- } \\
\text { ween layers. Maximum } \\
\text { thickness, } .065^{*} \text {. }\end{array}$ \\
\hline Dip & $\begin{array}{l}\text { Apply as received and as } \\
\text { a single layer. Maximum } \\
\text { thickness, 003: }\end{array}$ & \multicolumn{2}{|c|}{$\begin{array}{l}\text { Apply as received and as } \\
\text { a single layer. Maximum } \\
\text { thickness, } 003^{*} \text {. }\end{array}$} & \multicolumn{2}{|c|}{$\begin{array}{l}\text { Dilute coating as received } \\
\text { with distilled water. By } \\
\text { volume, } 5 \text { parts water to } 2 \\
\text { parts coating. If peeling } \\
\text { occurs, dilute to } 3 \text { to } 1 \text {. Air } \\
\text { dry } 45 \text { minutes between } \\
\text { tyyers. Maximum } \\
\text { thickness, 010". }\end{array}$} & $\begin{array}{l}\text { Apply initial layer as receiv- } \\
\text { ed. Air dry } 1 \text { to } 1.5 \text { hours. } \\
\text { Subsequent layers: dilute } \\
\text { to } 10 \text { parts coating to } 1 \\
\text { part distilled water. Max- } \\
\text { inum thickness, } .065^{*} \text {. }\end{array}$ \\
\hline $\begin{array}{l}\text { Curing } \\
\text { Drying and heat treatment }\end{array}$ & $\begin{array}{l}\text { Air dry for } 6 \text { hours, then at } \\
200^{\circ} \mathrm{F} \text { for } 4 \text { hours. Can be } \\
\text { polisthed with a sot towel } \\
\text { or cloth. Heat at } 850^{\circ} \mathrm{F} \text { for } \\
2 \text { hours to increase hard- } \\
\text { ness and permit applica. } \\
\text { tion of additional layers. }\end{array}$ & \multicolumn{2}{|c|}{$\begin{array}{l}\text { Air dry tor } 6 \text { hours. then at } \\
200^{\circ} \text { f for } 4 \text { hours. Can be } \\
\text { polished with a soti lowel } \\
\text { or cloth. Heat at } 850^{\circ} \text { F. for } \\
2 \text { hours to increase hard- } \\
\text { ness and permit applica. } \\
\text { tion of additional layers. }\end{array}$} & \multicolumn{2}{|c|}{$\begin{array}{l}\text { Air dry for } 4 \text { hours. then at } \\
200^{\circ} \text { for } 4 \text { hours. Can be } \\
\text { polished with soft towel or } \\
\text { cloth. Will not become } \\
\text { trarder with higher heat } \\
\text { treatment. }\end{array}$} & $\begin{array}{l}\text { Air dry for } 2 \text { hours, then at } \\
200^{\circ} \text { for } 4 \text { hours. Heal to } \\
150^{\circ} \text { f for } 2 \text { hours to } \\
\text { develop maximum } \\
\text { hardness. }\end{array}$ \\
\hline
\end{tabular}




\section{Appendix 2}

\section{Coupon Dimensions and Surface Condition}

\begin{tabular}{|c|c|c|c|c|}
\hline \multirow{2}{*}{$\begin{array}{c}\text { Materials } \\
\text { Tested }\end{array}$} & \multirow{2}{*}{$\begin{array}{l}\text { Material } \\
\text { Condition }\end{array}$} & \multicolumn{3}{|c|}{ Dimensions (in/cm) } \\
\hline & & Thickness & Width & Length \\
\hline \multirow[t]{12}{*}{$304 \mathrm{~L}$} & As Received & $0.125 / 0.318$ & $4 / 10.2$ & $6 / 15.2$ \\
\hline & Polished 1 micron & $0.125 / 0.318$ & $4 / 10.2$ & $6 / 15.2$ \\
\hline & Polished 600 grit (17 micron) & $0.125 / 0.318$ & $4 / 10.2$ & $6 / 15.2$ \\
\hline & Gold Plated $(0.0001$ in) & $0.125 / 0.318$ & $4 / 10.2$ & $6 / 15.2$ \\
\hline & Silver Plated (0.0001 in) & $0.125 / 0.318$ & $4 / 10.2$ & $6 / 15.2$ \\
\hline & Dense Chromium (Armoloy) & $0.125 / 0.318$ & $4 / 10.2$ & $6 / 15.2$ \\
\hline & Dense Cr (Armoloy) polished & $0.125 / 0.318$ & $4 / 10.2$ & $6 / 15.2$ \\
\hline & Oxidized $400^{\circ} \mathrm{C}$ & $0.125 / 0.318$ & $4 / 10.2$ & $6 / 15.2$ \\
\hline & Siliconized Alon & $0.125 / 0.318$ & $3 / 7.6$ & $3 / 7.6$ \\
\hline & ChromePlex ${ }^{\mathrm{TM}}(\mathrm{Cr} / \mathrm{Si})$ Alon & $0.125 / 0.318$ & $3 / 7.6$ & $3 / 7.6$ \\
\hline & Bidiffused (Cr/Al/Si) Alon & $0.125 / 0.318$ & $3 / 7.6$ & $3 / 7.6$ \\
\hline & Polished 600 grit (17 micron) & $0.375 / 0.953$ & $4 / 10.2$ & $6 / 15.2$ \\
\hline Inconel 690 & Oxidized $900^{\circ} \mathrm{C}$ & $0.125 / 0.318$ & $4 / 10.2$ & $6 / 15.2$ \\
\hline \multirow[t]{9}{*}{ Oxygen-Free Copper } & As Received & $0.125 / 0.318$ & $4 / 10.2$ & $6 / 15.2$ \\
\hline & Polished 1 micron & $0.125 / 0.318$ & $4 / 10.2$ & $6 / 15.2$ \\
\hline & Polished 600 grit (17 micron) & $0.125 / 0.318$ & $4 / 10.2$ & $6 / 15.2$ \\
\hline & Gold Plated (0.0001 in) & $0.125 / 0.318$ & $4 / 10.2$ & $6 / 15.2$ \\
\hline & Silver Plated (0.0001 in) & $0.125 / 0.318$ & $4 / 10.2$ & $6 / 15.2$ \\
\hline & Dense Chromium (Armoloy) & $0.125 / 0.318$ & $4 / 10.2$ & $6 / 15.2$ \\
\hline & Dense Cr (Armoloy) Polished & $0.125 / 0.318$ & $4 / 10.2$ & $6 / 15.2$ \\
\hline & Oxidized $900^{\circ} \mathrm{C}$ & $0.125 / 0.318$ & $4 / 10.2$ & $6 / 15.2$ \\
\hline & Polished 600 grit (17 micron) & $0.375 / 0.953$ & $4 / 10.2$ & $6 / 15.2$ \\
\hline Sterling Silver & Polished 600 grit (17 micron) & $0.25 / 0.635$ & $2.0 / 5.1 \mathrm{dia}$ & - \\
\hline Consil $^{\circ} 995$ & As Received (better than 600 grit) & $0.125 / 0.318$ & $2.6 / 6.5$ & $4.2 / 10.7$ \\
\hline Consil $^{\circ} 995$ & As Received (better than 600 grit) & 0.0121 .030 & $2.5 / 6.4$ & $2.5 / 6.4$ \\
\hline Consil $^{\oplus 995}$ & Oxidized $\left(732^{\circ} \mathrm{C}, 40\right.$ minutes) & 0.0121 .030 & $2.5 / 6.4$ & $2.5 / 6.4$ \\
\hline Aluminum (1100) & Polished 600 grit (17 micron) & $0.375 / 0.953$ & $4 / 10.2$ & $6 / 15.2$ \\
\hline Boron Nitride & Polished 600 grit (17 micron) & $0.291 / 0.737$ & $3.3 / 8.3 \mathrm{dia}$ & - \\
\hline Boron Nitride (Combat8) & Spray (304L Substrate) & $0.125 / 0.318$ & $4 / 10.2$ & $6 / 15.2$ \\
\hline Boron Nitride (Combat@) & Paste Type A (304L Substrate) & $0.125 / 0.318$ & $4 / 10.2$ & $6 / 15.2$ \\
\hline Boron Nitride (Combat $(8)$ & Paste Type S (304L Substrate) & $0.125 / 0.318$ & $4 / 10.2$ & $6 / 15.2$ \\
\hline Graphite & Polished 600 grit (17 micron) & $0.375 / 0.953$ & $4 / 10.2$ & $4 / 10.2$ \\
\hline Carbon/Carbon Composite & As Received & $0.375 / 0.953$ & $4 / 10.2$ & $4 / 10.2$ \\
\hline Nickel 200 & Polished 600 grit (17 micron) & $0.125 / 0.318$ & $4 / 10.2$ & $6 / 15.2$ \\
\hline Copper Nickel CDA706 & Polished 600 grit (17 micron) & $0.125 / 0.318$ & $4 / 10.2$ & $6 / 15.2$ \\
\hline
\end{tabular}




\section{Appendix 3}

Glass Sticking Temperatures For The Various Materials and Surface Coatings/Finishes.

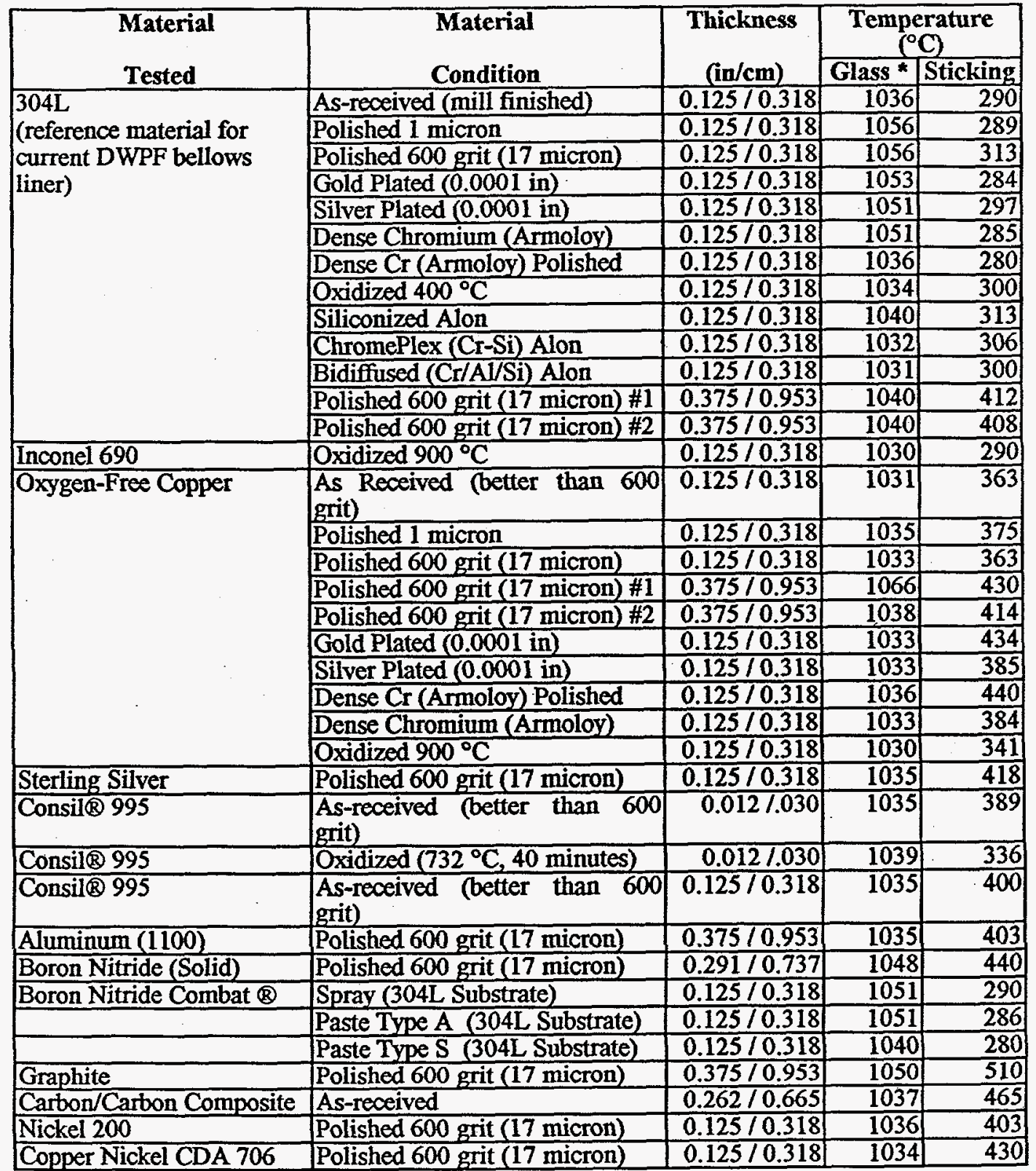

* Temperature of the glass in the melter. 


\section{Appendix 4}

Mechanical and Physical Properties of Selected Materials.

\begin{tabular}{|c|c|c|c|c|c|c|c|}
\hline \multirow[t]{2}{*}{$\begin{array}{c}\text { Material } \\
\text { Tested }\end{array}$} & \multirow{2}{*}{\begin{tabular}{|c|}
$\begin{array}{c}\text { Melting } \\
\text { Point } \\
\left({ }^{\circ} \mathrm{C}\right) \\
\end{array}$ \\
\end{tabular}} & \multirow{2}{*}{$\begin{array}{c}\text { Thermal } \\
\text { Conductivity } \\
\left(\mathrm{W} / \mathrm{m}^{\circ} \mathrm{C}\right)\end{array}$} & \multirow{2}{*}{$\begin{array}{c}\text { Linear } \\
\text { Expansion } \\
\text { Coefficient } \\
\text { (um } / \mathrm{m}^{\circ} \mathrm{C} \text { ) } \\
\end{array}$} & \multicolumn{4}{|c|}{$\begin{array}{c}\text { Mechanical Properties @ } \\
\left(22 / 400^{\circ} \mathrm{C}\right)\end{array}$} \\
\hline & & & & $\begin{array}{l}\text { Yield } \\
\text { (Ksi) }\end{array}$ & \begin{tabular}{|c|} 
Ultimate \\
(Ksi)
\end{tabular} & $\begin{array}{l}\text { Yield } \\
\text { (Ksi) }\end{array}$ & $\begin{array}{c}\text { Ultimate } \\
\text { (Ksi) }\end{array}$ \\
\hline $304 \mathrm{~L}$ & 1400 & 16 & 17.3 & 35 & 82 & 14 & 57 \\
\hline Inconel 690 & 1350 & 20 & 14.0 & 51 & 102 & 38 & 85 \\
\hline $\begin{array}{l}\text { Oxygen-Free Copper } \\
(99 \mathrm{wt} \% \mathrm{cu})\end{array}$ & 1080 & 389 & 16.7 & 10 & 32 & - & 15 \\
\hline $\begin{array}{l}\text { Sterling Silver } \\
(92 \text { wt } \% \text { Ag / } 8 \text { wt\% Cu) }\end{array}$ & 960 & 418 & 19.1 & - & 25 & - & 12 \\
\hline $\begin{array}{l}\text { Consil® } 995 \\
(99.5 \mathrm{Ag} / .25 \mathrm{Ni} / .25 \mathrm{Mg})^{3}\end{array}$ & 960 & 418 & 19.1 & 47 & 56 & 47 & 56 \\
\hline $\begin{array}{l}\text { Aluminum } 1100 \\
(99.9 \mathrm{wt} \% \mathrm{Al})\end{array}$ & 657 & 222 & 23.6 & 5 & 13 & 1.6 & 2 \\
\hline $\begin{array}{l}\text { Nickel } 200 \\
(99.9 \mathrm{wt} \% \mathrm{Ni})\end{array}$ & 1440 & 61 & 11.9 & 22 & 67 & 17 & 44 \\
\hline $\begin{array}{l}\text { Copper Nickel CDA } 706 \\
(90 \mathrm{Cu} / 10 \mathrm{Ni}) \\
\end{array}$ & 1120 & 45 & 16.7 & 16 & 40 & 14 & 25 \\
\hline $\begin{array}{l}\text { Boron Nitride } \\
\text { (Solid } 99.9 \mathrm{wt} \% \text { ) }\end{array}$ & 3000 & 55 & 0.3 & - & -- & - & - \\
\hline Graphite & 3665 & 32 & 7.8 & - & - & $-\cdots$ & - \\
\hline Carbon/Carbon Composite & 2200 & 3 & 3.0 & - & - & - & $\ldots$ \\
\hline
\end{tabular}

1 Data at $400^{\circ} \mathrm{C}$

2 Data at $100^{\circ} \mathrm{C}$

3 Mechanical properties after oxidation hardening 


\section{Appendix 5}

\section{Material Selection Considerations (Relative Ranking)}

\begin{tabular}{|l|c|c|c|c|c|}
\hline \multicolumn{1}{|c|}{$\begin{array}{c}\text { Candidate } \\
\text { Materials }\end{array}$} & $\begin{array}{c}\text { Total } \\
\text { Cost }^{1,2}\end{array}$ & Fabricability & $\begin{array}{c}\text { Corrosion / Oxidation } \\
\text { Resistance }\left(300-500^{\circ} \mathrm{C}\right)^{3}\end{array}$ & Availability & $\begin{array}{c}\text { Affect Waste } \\
\text { Qualification }\end{array}$ \\
\hline $304 \mathrm{~L}$ & 5 & 5 & 5 & Yes & No \\
\hline Inconel 690 & 3 & 3 & 8 & Yes & No \\
\hline Copper & 7 & $8^{4}$ & 3 (corrosion / oxidation) & Yes & No \\
\hline Consil[ 995 & 4 & $4^{4}$ & 3 (general corrosion) & Yes & No \\
\hline Nickel 200/201 & 3 & 6 & $\begin{array}{c}6 \text { (sulfidation at elevated } \\
\text { temperatures) }\end{array}$ & Yes & No \\
\hline Boron Nitride & NA & NA & $8^{5}$ & No & No \\
\hline $\begin{array}{l}\text { Carbon/Carbon } \\
\text { Composite }\end{array}$ & 2 & 2 & 7 (oxidation at elevated \\
temperatures) & Yes & $\begin{array}{c}\text { Evaluation } \\
\text { Required }\end{array}$ \\
\hline
\end{tabular}

1 - Scale 1 to 10 , relative to Type 304L stainless steel (5), $1=$ most costly, most difficult to fabricate, most prone to corrosion/oxidation.

2 - Material and fabrication costs

3 - Testing was performed in air. The performance of these materials in the actual pour spout environment is unknown.

4 - Will require special welding/brazing materials

5 - May result in corrosion of pour spout components at elevated temperatures 
Revision 0

DISTRIBUTION:

D.F. Bickford, 773-43A

R.L. Bickford, 730-A

T. L. Capeletti, 773-41A

J.T. Carter, 704-25S

G.T. Chandler, 773-A

R.E. Edwards, 704-25S

J.T. Gee, 704-25S

C.R. Goetzman Jr., 773-A

T.C. Gunter, 704-S

P.S. Hebert, 723-A

E.W. Holtzscheiter, 773-A

R.C. Hopkins, 704-27S

D.C. Iverson, 704-30S

N. C. Iyer, 773-A

C.F. Jenkins, 730-A

W.D. Kerley, 704-25S

M.A. Kyle, 723-A

D.P. Lambert, 704-1T

L.F. Landon, 704-1T

T.J. Lex, 719-4A

D.B. Little, $210-S$

J.P. Morin, 719-4A

T.A. Nance, 723-A

R.J. ODriscoll, 704-30S

J.F. Ortaldo, 704-S

J.E. Owen, 704-30S

L.M. Papouchado, 773-A

S.F. Piccolo, 704-S

C.T. Randall, 704-T

D.T. Rankin, 773-A

J.F. Sproull, 704-30S

J.L. Steele, 773-A

J.P. Veldman, 773-A

G.G. Wicks, 773-A

C.R. Wolfe, 773-A

S. Wood, 773-A

G.T Wright, 773-A

MTS Files, 773-A

TIM, 703-43A (4) 